\title{
The Important Role of Organizational Justice as Predictor of HR Performance
}

\author{
Siti Haerani ${ }^{1}$, Sumardi $^{2}$, Wardhani Hakim ${ }^{3}$, Hartini ${ }^{4}$, Achmad Fatri Gandrasula ${ }^{5}$ \\ \{haeranisiti68@yahoo.co.id ${ }^{1}$, sumardilasise@gmail.com²,wardhanihakim@ymail.com³ \\ hartini@yahoo.com ${ }^{4}$,fgandrasula@yahoo.co.id ${ }^{5}$ \}
}

Universitas Hasanuddin, Makassar, Indonesia ${ }^{1-5}$

\begin{abstract}
This study aims to examine the effects: Organizational justice towards organizational commitment, OCB and employee performance. The survey was conducted on three companies with a sample of 90 employees. Data is collected through a questionnaire and then analyzed using Structural Equation Modeling. The results showed that: The influence of organizational justice on organizational commitment, OCB and employee performance is significant. So that it contributes both practical and theoretical to the need for company leaders to prioritize fair treatment in the reward system for employees in the process of improving their performance going forward.
\end{abstract}

Keywords: person-organization Fit (PO Fit), Organizational Justice, Organizational Commitment, OCB, Job Satisfaction, Human Resources Performance

\section{Introduction}

The study of person-organization Fit (PO Fit), organizational justice, job satisfaction and organizational commitment and OCB is a study in the field of organizational behavior [1] which is very important because it combines individual aspects and organizational aspects as determinants to the performance of employees and organizations especially in SOEs in South Sulawesi. Aspects of the organization are identified through PO Fit, which reflects the extent to which the practice of recruitment and placement of employees is carried out appropriately based on the suitability of competencies, goals and values held between individuals and organizations. Other aspects of the organization are identified through organizational justice variables that reflect the extent to which the practice of rewards or compensation given by the organization is felt fairly by employees. While individual aspects will be identified through job satisfaction, organizational commitment, citizenship behavior (Organizational Citizenship Behavior $=\mathrm{OCB}$ ) and the performance contributed by employees to their organizations, so this research becomes very important and different from previous studies on the same thing both in terms of scope and organization of the object of study. The findings of this study certainly will contribute to the development of science, especially to the science of Organizational Behavior and Human Resource Management.

The argument supporting the importance of this research is that an unsuitable (unfit) employee placement system will give birth to employees who are incompetent and dissatisfied and not committed and will not even behave as good organizational citizenship (Organization Citizenship Behavior $=$ OCB) so that it will adversely affect performance achieved [2],[3], [4], [5], [6]. Likewise, if employees are not valued fairly and fairly both financially and non- 
financially (career) will give birth to people who are dissatisfied with work, no commitment, let alone OCB behavior is very difficult to expect so that organizational performance can continue to decline. Thus, any organization, whether business, public or social, needs to be supported by people who are competent fit and gets a fair and fair award so that their performance can be realized as expected [6], [7].

The descriptions above are the main reasons for the importance of this study to reexamine the suitability of people with the organization (PO Fit) and their work, especially if combined with the perception of organizational justice (Organizational Equity) in valuing employees can improve the performance of employees contributed to the organization through satisfactory work and perceived organizational commitment, and voluntary behavior of employees at work, especially for state-owned organizations.

\section{Literature review}

Sekiguchi (2007) describes Person-Organization Fit (PO Fit) as the suitability of prospective employees with organizational attributes [8]. This suitability is described by Kristof (1996) includes four aspects: the suitability of the value (value congruence), fitness for purpose (goal congruence), meeting the needs of employees (employee need fulfillment), and suitability characteristics-personality culture (culture personality congruence) [8]. When individual and organizational values are the same, this will increase job satisfaction and performance and will reduce employee work stress. The suitability of Individual values will make individuals feel interested and comfortable working [9] and interacts easily and efficiently with organizational systems. Thus, it will provide job satisfaction, reduced stress, reduce uncertainty, prevent conflict and increase intrinsic motivation [10], organizational commitment, OCB, and employee performance [2], [6], [8]. This has been proven by Chadwell, Chatman and O'Reilly (1991) the influence of $P O$ Fit on job satisfaction and performance, although in the study of Aurthy \& Daugherty (2003) found the opposite situation where PO Fit had no effect on job satisfaction [4].

Furthermore, organizational justice (organizational justice) is defined by as employees' perceptions of neutrality in terms of procedures, interactions and results obtained in the workplace. Organizational justice is guided by the theory of justice which states that employees tend to compare between what they get (output: salary, facilities, positions, etc.) from their work in return for contributions made (inputs: effort, energy, experience, education, skills, creativity, creativity) etc.) compared to what other people or coworkers get (comparative output) compared to the contribution made by their coworkers (comparative input). If the results of the comparison are equal, then it means there is justice, on the contrary if the results of the comparison are not equal or different then it means there is injustice [11].

Organizational justice can be judged on the basis of three classifications of circumstances namely the results they receive from the organization (distributive justice), formal policies or processes by which an outcome is allocated (procedural justice), and the treatment given by decision makers between individuals within the organization (interactional justice) [12]. States that the perception of organizational justice is an antecedent of positive organizational justice and citizenship behavior (OCB), job satisfaction, and organizational commitment. Several previous studies have shown a close relationship between organizational justice and citizenship behavior (OCB) and higher performance and job satisfaction [12]. 
Performance is an activity related to work and how these activities are carried out [13]. Performance is related to work results and behavior. Armstrong added, as a behavior, performance is a human activity that is directed at the implementation of organizational tasks assigned to it. Employee performance is also related to how much they contribute to the organization which includes the quantity of output, the quality of output, and the period of time of output, workplace attendance and cooperative attitude.

Several studies have proven several performance antecedents including job satisfaction [14], [15],[16], [17], [18], [19], [20], [21]. organizational commitment and OCB [20].

\section{Research methods}

The study uses cross-sectional data from three SOEs located in Makassar City, South Sulawesi with a total sample of 30 non-managerial employees from each SOE so that the total sample is 90 people. A questionnaire is used as a data collection instrument, with alternative answers prepared and expressed in a Likert scale of 1-5. Data is processed using Structural Equation Modeling (SEM).

\section{Research result}

\subsection{Descriptive Characteristics of Respondents}

Characteristics of respondents in terms of gender, male $(93.33 \%)$ far more than female respondents (only $6.67 \%$ ). The highest age is between $31-40$ years as much as $63.33 \%$, aged 21-30 years as much as $12.22 \%$ and above 40 years as much as $24.45 \%$. The education level of respondents showed the highest number, namely Strata One (S-1) ie 67.78\%, Strata Two (S2) $18.89 \%$. Diploma education level is $11.11 \%$, and high school is $2.22 \%$. The most work period is above 11 years is $75.56 \%$, while the rest is less than 10 years of work is $24.45 \%$.

\subsection{Descriptive Research Variables}

Table 1. Description of Mean Values of Variables and Indicators

\begin{tabular}{|c|c|c|c|c|}
\hline No & Variable & $\begin{array}{l}\text { Average } \\
\text { Variable }\end{array}$ & Highest indicator & Lowest indicator \\
\hline 1 & $\begin{array}{l}\text { Person-Organization } \\
\text { Fit }\end{array}$ & 3.91 & $\begin{array}{l}\text { X141 - Suitability of } \\
\text { performance appraisal } \\
(4.34)\end{array}$ & $\begin{array}{l}\text { X111 - Submission } \\
\text { of values (3.47) }\end{array}$ \\
\hline 2 & Organizational justice & 3.84 & $\begin{array}{l}\text { X221 - Detailed } \\
\text { compensation (4.06) }\end{array}$ & 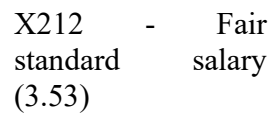 \\
\hline 3 & Job satisfaction & 3.85 & $\begin{array}{l}\text { Y121 - Methods of work } \\
(4.06)\end{array}$ & $\begin{array}{l}\text { Y131 } \\
\text { Relationship with } \\
\text { coworkers (3.61) }\end{array}$ \\
\hline 4 & $\begin{array}{l}\text { Organizational } \\
\text { Commitment }\end{array}$ & 3.93 & $\begin{array}{l}\text { Y212 - Responsibilities } \\
(4.05)\end{array}$ & $\begin{array}{l}\text { Y222 - Feelings of } \\
\text { debt of gratitude } \\
(3.83)\end{array}$ \\
\hline
\end{tabular}




\begin{tabular}{lllll}
\hline 5 & OCB & 3.82 & $\begin{array}{l}\text { Y312 - Helping } \\
\text { colleagues without being } \\
\text { asked }(4,14)\end{array}$ & $\begin{array}{l}\text { Y342 - Attention to } \\
\text { development (3.33) }\end{array}$ \\
6 & Employee performance & 3.44 & $\begin{array}{l}\text { Y421 - The best quality } \\
\text { of work }(3.55)\end{array}$ & $\begin{array}{l}\text { Y442 - Complete } \\
\text { before the deadline } \\
(3.30)\end{array}$ \\
\hline
\end{tabular}

Source: Primary Processed Data Results, 2019

The above table shows that the variables with the highest average values are: organizational commitment (3.93), PO Fit (3.91), job satisfaction (3.85), organizational justice (3.84) and employee performance (3.44).

\subsection{Structural Model Test}

The T-value (Critical Ratio) of the majority of the variable relationship path shows a CR value of 1.960, which indicates a positive and significant effect, except the relationship between person organization fit to organizational commitment and OCB shows an insignificant effect based on a CR value smaller than 1.960. A detailed path coefficient is presented in the following table:

Table 2. Results of Structural Model Analysis of Relationships Between Variables

\begin{tabular}{|c|c|c|c|c|c|}
\hline Influencing variable & Variable affected & Estimate & $\begin{array}{l}\text { T value } \\
\text { (Critical } \\
\text { Ratio) }\end{array}$ & p-value & Description \\
\hline $\begin{array}{l}\text { Person Organization } \\
\text { Fit }\end{array}$ & Job satisfaction & 0.450 & 2.560 & 0.010 & Significant \\
\hline $\begin{array}{l}\text { Person Organization } \\
\text { Fit }\end{array}$ & $\begin{array}{l}\text { Organizational } \\
\text { Commitment }\end{array}$ & 0.213 & 0.971 & 0.331 & $\begin{array}{l}\text { Not } \\
\text { significant }\end{array}$ \\
\hline $\begin{array}{l}\text { Person Organization } \\
\text { Fit }\end{array}$ & OCB & 0.192 & 0.854 & 0.393 & $\begin{array}{l}\text { Not } \\
\text { significant }\end{array}$ \\
\hline $\begin{array}{l}\text { Organizational } \\
\text { Justice }\end{array}$ & $\begin{array}{l}\text { Organizational } \\
\text { Commitment }\end{array}$ & 0.228 & 2.389 & 0.017 & Significant \\
\hline $\begin{array}{l}\text { Organizational } \\
\text { Justice }\end{array}$ & $\mathrm{OCB}$ & 0.199 & 2.208 & 0.027 & Significant \\
\hline $\begin{array}{l}\text { Organizational } \\
\text { Justice }\end{array}$ & Job satisfaction & 0.228 & 3.143 & 0.002 & Significant \\
\hline $\begin{array}{l}\text { Organizational } \\
\text { Commitment }\end{array}$ & $\begin{array}{l}\text { Employee } \\
\text { performance }\end{array}$ & 0.347 & 2.919 & 0.004 & Significant \\
\hline Job satisfaction & $\begin{array}{l}\text { Employee } \\
\text { performance }\end{array}$ & 0.405 & 2.049 & 0.040 & Significant \\
\hline $\mathrm{OCB}$ & $\begin{array}{l}\text { Employee } \\
\text { performance }\end{array}$ & .242 & 2.352 & 0.019 & Significant \\
\hline
\end{tabular}

Source: Primary Data After Processing, 2019 


\section{Discussion}

\subsection{Implications of PO Fit on Job Satisfaction, Organizational Commitment, OCB and employee performance}

The coefficient of influence of the $P O$ fit variable (X1) on job satisfaction (Y1) is 0.450 with a $t$ value of 2.560 , with a probability value of 0.010 , indicating that $P O$ fit has a positive and significant effect on job satisfaction. The meaning of this finding is that the employee will be satisfied to work if he feels he gets a suitable job and this will have implications for better performance. This finding is in line with the principle of employee placement "The right man on the right place" needs to be applied to the SOE companies that are the object of this study.

The coefficient of influence of the POfit variable (X1) on organizational commitment (Y2) is 0.213 , with a t value of 0.971 and a probability value of 0.331 . This means that $P O$ fit does not have a significant effect on organizational commitment, so it can be stated that the suitability of work between individuals and the organization does not guarantee employees to commit to the organization and its goals and maintain its presence in the organization. Even though the employee feels suitable for the job and the organization, there is still the possibility of leaving the job when he feels there are other more attractive job options. Conversely, the incompatibility of employees with their work and organization cannot always be a motivating factor for employees to immediately leave their work and look for other jobs, especially for employees who feel they have less choice of other jobs that are better than the current job.

The coefficient of influence of the $P O$ fit (X1) variable on OCB (Y3) is 0.192 with a $t$ value of 0.854 and a probability value of 0.393 . This means that $P O$ fit also has an insignificant effect on OCB. The findings of this study reflect that $P O$ fit does not necessarily make employees willing to go the extra mile beyond their responsibilities. The argument that can support this finding is that OCB is closely related to one's personality. So even if someone has competency suitability with his job, it may be constrained by the limits of authority possessed by each employee to do something outside of his main duties. In addition, the competencies possessed are not necessarily compatible with the competencies required by other jobs that require assistance.

\subsection{Implications of Organizational Justice for Organizational Commitment, Job Satisfaction and OCB and Employee Performance}

The coefficient of influence of the organizational justice variable (X2) on organizational commitment (Y2) is 0.228 with a $t$ value of 2.389 , with a probability value of 0.017 . This means that organizational justice has a positive and significant effect on organizational commitment. This finding can be interpreted that the more equitable treatment of employees both distributive, procedurally and interactively will further strengthen employee attachment to the organization both mentally/emotionally (affective commitment) and physically, both because of conscience considerations (affective commitment), profit and loss (profit) continuity commitment) and rules (normative commitment).

The coefficient of influence of organizational justice variables (X2) on OCB (Y3) is 0.199 with a $t$ value of 2.208 with a probability value of 0.027 . This means that organizational justice has a positive and significant effect on OCB. The meaning of the finding is that the higher the fair treatment felt by employees, the more the spirit of employee generosity to get more work done, even though it is outside the responsibilities or demands of work, even more 
eager to help other coworkers complete their work without expecting any reward or repayment from co-workers assisted. This behavior really is voluntary behavior, like and voluntary behavior means there is the sincerity of doing it. A sincere person means expecting no reward, not expecting praise or reward.

The coefficient of influence of organizational justice variables (X2) on job satisfaction (Y1) is 0.228 , with a $t$ value of 3.143 with a probability value of 0.002 . The coefficient shows that the organizational justice variable (X2) has a positive effect on job satisfaction (Y1). This means that an increase in organizational justice (X2) will be followed by an increase in job satisfaction (Y1), assuming other factors that affect the size of job satisfaction are considered constant.

This finding indicates that BUMN (State-Owned Enterprise) employees will increasingly feel satisfied and happy if they feel treated fairly. If employees are treated fairly then, they will get more passion of working because they realize that their work will be valued equally. Whoever works a lot will get more rewards too, conversely whoever works less will get a few rewards too.

\subsection{Implications of Organizational Commitment, Job Satisfaction and OCB on Employee Performance}

The coefficient of influence of organizational commitment variable (Y2) on employee performance (Y4) of 0.347 with $t$ value of 2.919 , the coefficient shows that the variable of organizational commitment (Y2) has a positive effect on employee performance (Y4). This means that an increase in organizational commitment (Y2), will be followed by an increase in employee performance (Y4). The findings of this study indicate that employees who have high commitment to work will produce higher performance, conversely, if employees' work commitment is low then the resulting performance will also be low. This indicates how important the work commitment of employees is built to support the development of performance.

The coefficient of influence of job satisfaction(Y1) variable on employee performance (Y4) is 0.405 with a $t$ value of 2.049 with a probability value of 0.040 . This means that job satisfaction(Y1) has a positive and significant effect on employee performance (Y4). This finding means that the more satisfied employees are with everything received from the company (salary, promotion, supervision, relationships with colleagues and fun jobs) will encourage them to perform better. In other words, "happy worker is a productive worker" is the real thing in this study.

The coefficient of influence of the OCB variable (Y3) on employee performance (Y4) is 0.242 with a $t$ value of 2.352 , with a probability value of 0.019 . This means OCB (Y3) has a positive and significant effect on employee performance (Y4). Thus it can be said that the higher the OCB employees the higher the performance will be. Employees who have high OCB will manifest in the form of work behavior that is willing and happy to help. They want to do work beyond the standard set for him without intending to get praise, rewards let alone financial rewards but solely because of the sincerity that comes voluntarily from him. Of course, if employees like to help others, coworkers or anyone else, then, of course, their own work will be completed much more perfect before helping others perfect their work sincerely and sincerely (unconditionally). 


\section{Conclusions and Recommendation}

Based on the results of hypothesis testing and the discussion in the previous chapter, it was concluded that: Person Organization Fit has a significant effect on Job Satisfaction while on Organizational Commitment, OCB and employee performance, the effect is not significant. Organizational justice has a positive and significant influence on Organizational Commitment, OCB, job satisfaction and employee performance. Furthermore, organizational commitment, job satisfaction and OCB, all three, have a positive influence on employee performance. Thus, organizational justice plays a more important role in influencing job satisfaction, organizational commitment and performance of State Owned Enterprise employees according to PO Fit so that it is recommended that SOE leaders need to treat all employees fairly, without having to look at their work, position or rank.

\section{References}

[1] Liu, B., Liu, J., Hu, J.: Person-Organization Fit, Job Satisfaction, and Turnover Intention: An Empirical Study in the Chinese Public Sector. Social Behavior and Personality, Vol. 38. pp. 615-626 (2010)

[2] Farooquia, S and Nagendrab, A.: The Impact of Person organization Fit on Job Satisfaction and Performance of the Employees. Procedia Economics and Finance.pp. 122 - 129 (2014)

[3] Kristof-Brown, A. L., Zimmerman, .R .D., and Johnson, E. C. : Consequences of individual' fit at work A Meta-Analysis of person-job, person-organization, person-group, and person-supervisor fit. Personal psycholog, Vol. 58,pp. 281-342 (2005)

[4] O'Reilly, C. A., Chatman, J. A., \& Caldwell, D. F.: People and Organizational Culture: a Profile Comparison Approach to Assessing Person organization Fit Vol. 34, pp. 487-516 (1991)

[5] Nazir,A,. Saima.: Person - Organization fit and Organizational Outcome Variables: A Review. International Journal of Business and Management Invention. Vol 3, pp.54-58 (2014)

[6] Tepeci, Mustapha. : The Effect of Personal Values, Organizational Culture, Person Organization Fit on Individual Outcomes in Restaurant Industry. A Thesis in Man-Environment Relations. The Pennsylvania State University. The Graduate Schoolof Hotel, Restaurant and Recreation Management (2001)

[7] Boxx, W. R., Odom, R. Y., and Dunn, M. G.: Organizational Values and Value Congruency and Their Impact on Satisfaction, Commitment, and Cohesion: An Empirical Examination Within the Public Sector. Public Personnel Management, Vol. 20 pp. 195-205. (1991)

[8] Kristof, A. L.: Person-Organization Fit (P-O Fit): an Integrative Review of Its Conceptualizations, Measurement, and Implications. Personnel Psychology. Vol. 49,pp. 1-49 (1996)

[9] Schneider, B.: The people make the place. Personnel Psychology, Vol 40,pp. 437-453 (1987)

[10] Saether, Erik Andreas.: Motivational Antecedents To High-Tech R\&D Employees' innovative Work Behavior: Self-determined motivation, person-organization fit, organization support of creativity, and pay justice (2019)

[11] Robbins, S and Coulter, M. : Manajemen, Edisi Kedelapan, Penerbit PT Indeks, Jakarta (2007)

[12] Cropanzano, R., Prehar, C.A., \& Chen, P.Y. : Using social exchange theory to distinguish procedural from interactional justice. Group \& Organization Mangement (2000)

[13] Dugguh, S. Dennis, A.: Job Satisfaction Theories: Traceability to Employee Performance in Organizations. Vol. 16 (2014)

[14] Carmeli,A. Freund,A.: Work Commitment, Job Satisfaction, Job Performance: an Empirical Investigation. Vol. 6, pp. 289-309 (2004) 
[15] Rose, R., C., Kumar, N., Pak, O., G. 2009. The Effect Of Organizational Learning On Organizational Commitment, Job Satisfaction And Work Performance. The Journal of Applied Business Research. Vol. 25, No. 6.

[17] Ostroff.C.1992. The Relationship between Satisfaction,Attitude, and Performance: An Organizational Level Analysis. Journal of Applied Psy-chology. Vol 77. P963-974.

[18] Zeinabadi, H. 2010. Job satisfaction and organizational commitment as antecedents of Organizational Citizenship Behavior (OCB) of Teachers, Procedia Social and Behavioral

Sciences 5: 998-1003

[19] Imran, H., Arif, I., Cheema, S., Azeem, M. 2014. Relationship between Job Satisfaction, Job Performance, Attitude towards Work, and Organizational Commitment. Entrepreneurship and Innovation Management Journal, Vol. 2, No. 2, pp. 135-144.

[20] Chen, L. Y. 2002. An examination of the Relationship Between Leadership Behavior and Organizational Commitment at Steel Companies. Journal of Applied Management and Entrepreneurship, 7, 122-142.

[21] Talasaz, Z., H., Saadoldin, S., N., Shakeri, M., T. 2014. The Relationship between Job Satisfaction and Job Performance among Midwives Working in Healthcare Centers of Mashhad, Iran. Journal Midwifery Reproduktif Health. 2(3):157-164. 